\title{
Correction to: Air pollution, methane super- emitters, and oil and gas wells in Northern California: the relationship with migraine headache prevalence and exacerbation
}

Holly Elser ${ }^{1}$, Rachel Morello-Frosch², Alice Jacobson ${ }^{3}$, Alice Pressman³, Marianthi-Anna Kioumourtzoglou 4 , Richard Reimer ${ }^{5}$ and Joan A. Casey ${ }^{4^{*}}$

Correction to: Environ Health 20, 45 (2021)

https://doi.org/10.1186/s12940-021-00727-w

Following the publication of the original article [1], it was noted that due to a typesetting error the actual figures for Figures 2 and 3 were interchanged.

The original article has been updated.

\begin{abstract}
Author details
'Stanford University School of Medicine, Stanford Center for Population Health Sciences, Stanford, USA. ${ }^{2}$ Department of Environmental Science, Policy, and Management and School of Public Health, University of California Berkeley, Berkeley, CA, USA. ${ }^{3}$ Research, Development and Dissemination, Sutter Health, Sacramento, USA. ${ }^{4}$ Department of Environmental Health Sciences, Mailman School of Public Health, Columbia University, 722 W 168th St, Rm 1206, New York, NY 10032-3727, USA. ${ }^{5}$ Department of Neurology and Neurological Science, Stanford University School of Medicine, Stanford, USA.
\end{abstract}

Published online: 10 May 2021

\section{Reference}

1. Elser H, Morello-Frosch R, Jacobson A, et al. Air pollution, methane superemitters, and oil and gas wells in Northern California: the relationship with migraine headache prevalence and exacerbation. Environ Health. 2021;20(1): 45. https://doi.org/10.1186/s12940-021-00727-w.

\footnotetext{
The original article can be found online at https://doi.org/10.1186/s12940021-00727-w.

*Correspondence: jac2250@cumc.columbia.edu

${ }^{4}$ Department of Environmental Health Sciences, Mailman School of Public

Health, Columbia University, 722 W 168th St, Rm 1206, New York, NY

10032-3727, USA

Full list of author information is available at the end of the article
}

(c) The Author(s). 2021 Open Access This article is licensed under a Creative Commons Attribution 4.0 International License, which permits use, sharing, adaptation, distribution and reproduction in any medium or format, as long as you give appropriate credit to the original author(s) and the source, provide a link to the Creative Commons licence, and indicate if changes were made. The images or other third party material in this article are included in the article's Creative Commons. licence, unless indicated otherwise in a credit line to the material. If material is not included in the article's Creative Commons licence and your intended use is not permitted by statutory regulation or exceeds the permitted use, you will need to obtain permission directly from the copyright holder. To view a copy of this licence, visit http://creativecommons.org/licenses/by/4.0/ The Creative Commons Public Domain Dedication waiver (http://creativecommons.org/publicdomain/zero/1.0/) applies to the data made available in this article, unless otherwise stated in a credit line to the data. 